\title{
Zinc status in HIV infected Ugandan children aged 1-5 years: a cross sectional baseline survey
}

Grace Ndeezi ${ }^{1,2^{*}}$, James K Tumwine', Bjørn J Bolann, Christopher M Ndugwa', Thorkild Tylleskär²

\begin{abstract}
Background: Low concentrations of serum zinc have been reported in HIV infected adults and are associated with disease progression and an increased risk of death. Few studies have been conducted in HIV infected children in Africa. We determined serum zinc levels and factors associated with zinc deficiency in HIV infected Ugandan children.

Methods: We measured the baseline zinc status of 247 children aged 1-5 years enrolled in a randomised trial for multiple micronutrient supplementation at paediatric HIV clinics in Uganda (http://ClinicalTrials.gov NCT00122941). Zinc status was determined using inductively coupled atomic emission spectrophotometry (ICP-AES). Clinical and laboratory characteristics were compared among zinc deficient (zinc $<10.0 \mu \mathrm{mol} / \mathrm{L}$ ) and non deficient children. Logistic regression was used to determine predictors of low serum zinc.

Results: Of the 247 children, 134 (54.3\%) had low serum zinc ( $<10.0 \mu \mathrm{mol} / \mathrm{L})$. Of the 44 children on highly active antiretroviral therapy (HAART), 13 (29.5\%) had low zinc compared to 121/203 (59.6\%) who were not on HAART. Overall, independent predictors of low zinc were fever (OR 2.2; 95\% Cl $1.1-4.6$ ) and not taking HAART (OR 3.7; 95\% Cl $1.8-7.6)$.

Conclusion: Almost two thirds of HAART naive and a third of HAART treated HIV infected children were zinc deficient. Increased access to HAART among HIV infected children living in Uganda might reduce the prevalence of zinc deficiency.
\end{abstract}

\section{Background}

Zinc deficiency is wide spread in low-income countries and is responsible for $4 \%$ of childhood deaths and $1 \%$ of the burden of disease in Africa, Latin America and Asia [1]. Populations in sub-Saharan Africa and South East Asia have the greatest risk of zinc deficiency because of inadequate zinc intake in about one third of the population [2].

Zinc is a component of various metallo-enzymes, proteins and cell membranes; and plays an important role in immune regulation. Zinc deficiency increases susceptibility to oxidative stress and impaired cell membrane function [3,4]. In HIV infected adults, low serum zinc has been associated with more advanced HIV disease and increased mortality [5-7].

\footnotetext{
* Correspondence: gracendeezi@yahoo.com

'Department of Paediatrics and Child Health, School of Medicine, College of Health Sciences, Makerere University, Kampala, Uganda

Full list of author information is available at the end of the article
}

Whereas some studies of HIV infected children in high-income countries have indicated that micronutrient deficiencies are uncommon [8], the reverse is true in low-income countries. The zinc status of HIV infected children in Uganda has not been reported. In this paper we report the magnitude of zinc deficiency and associated factors in a group of HIV infected children in Uganda.

\section{Methods \\ Study sites}

This study was part of a baseline assessment of children enrolled in a multiple micronutrient supplementation trial carried out between June 2005 and June 2008. This paper presents data from 3 of 7 clinics involved in the study, namely the paediatric HIV clinics at the national referral hospital (Mulago), Mildmay Centre and Nsambya hospital. These centres had laboratory facilities for blood sampling and freezing before transportation for analysis at a distant laboratory. Mulago is the national
Ciomed Central 
referral hospital; Mildmay Centre and Nsambya are private, not-for-profit hospitals. All the three are situated in the capital city, Kampala. The Mulago Hospital Paediatric HIV Clinic is the largest in the country and cares for more than 8000 patients. The Mildmay Centre, Uganda, is an HIV/AIDS referral and training institution, 12 kilometres South of Kampala city centre and cares for about 1500 HIV infected children, while Nsambya hospital cares for an equal number of HIV infected children.

\section{Design and subjects}

We here report the baseline zinc levels of children aged 1-5 years who enrolled in the multiple micronutrient supplementation (MMS) study (ClinicalTrials.gov Identifier: NCT00122941).

The MMS study was a randomised trial of a 14 vitamins and minerals versus a six multivitamin supplement as 'standard-of-care' for 6 months, among $847 \mathrm{HIV}$ infected children, with a highly active anti-retroviral therapy (HAART) strata comprising $10 \%$ of the study participants. The study enrolled HIV infected children who had at least attended the clinic once and were coming for follow-up. Those who were enrolled in other studies were excluded.

Children in the HAART strata had already been started on anti-retroviral therapy (ART) at the study clinics before enrolment into the study. The 2006 World Health Organization (WHO) guidelines for initiating anti-retroviral therapy in children had been used, in addition to a 'social criteria' that was conductive for initiating ART. Children aged 1 - 3 years were initiated on ART if their CD4+ T cell count was below $20 \%$ or if they had WHO stage 3 or 4 disease. Those above 3 years of age were initiated on ART if their CD $4+\mathrm{T}$ cell count was $<15 \%$ or if they had WHO stage 3 or 4 disease [9]. The social criteria meant that the child had a consistent caretaker who was adherent to previous clinic appointments, attended at least 2 counseling sessions on adherence to ART and had consented for initiation of therapy.

Due to cost, zinc was analysed at baseline only for children who had sufficient serum collected on both samplings (baseline and at 6-month follow-up). Of the 847 children who participated in the multiple micronutrient supplementation study, 705 were enrolled at the 3 sites where zinc analysis was possible. Two hundred and forty seven children of the 705 (35.0\%) had complete clinical data and laboratory analyses at baseline to be included in this paper (figure 1). Laboratory data was declared incomplete as long as a participant did not have one or more of the tests. Out of the 458 exclusions, 261 children had haematology and CRP results but no micronutrient test (zinc inclusive) result, 64 had other micronutrient

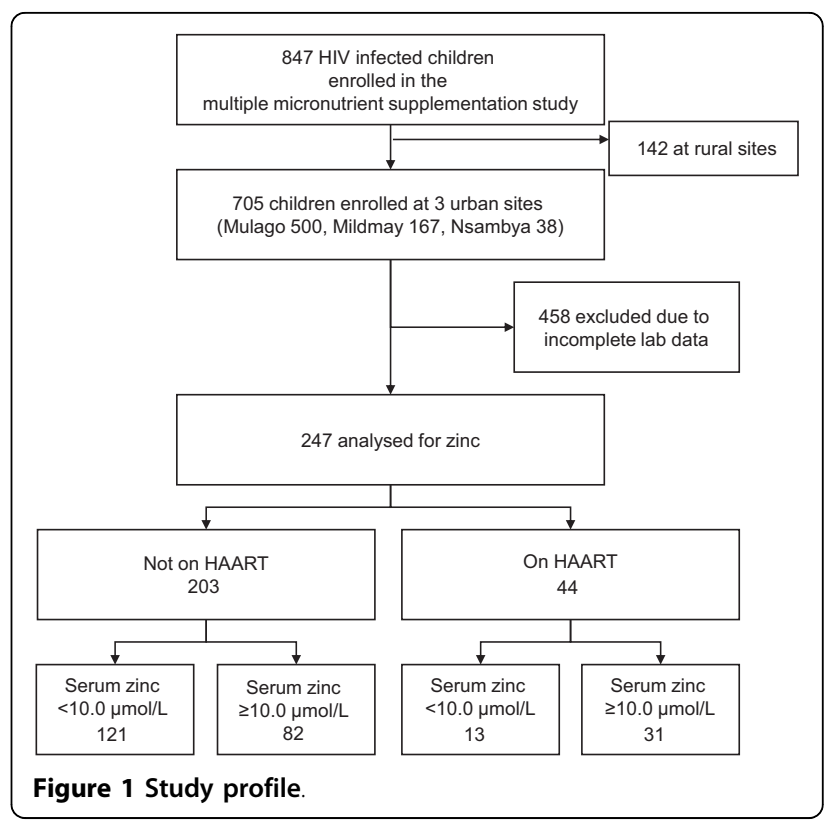

tests done except zinc, 89 had baseline zinc results but no second sample and 44 had missing samples. Overall insufficient samples contributed 414/458 exclusions while 44 were due to missing samples.

\section{Ethical issues}

Written informed consent from the mothers/caretakers was obtained in English or Luganda, one of the commonly spoken local languages in the study area. Permission to conduct the study was granted by Makerere University College of Health Sciences, the Mildmay Centre, Nsambya and Mulago hospitals Research and Ethics Committees. Permission was also granted by the Uganda National Council for Science and Technology and the Regional Committee for Medical and Health Research Ethics, Western Norway ("REK Vest"). Counselling for initiation of HAART and adherence was offered to those who were eligible to start antiretroviral therapy. Treatment for illness and prophylaxis was offered according to the $\mathrm{WHO}$ and national paediatric HIV management guidelines.

\section{Procedures \\ History and physical examination}

Mothers/caretakers were interviewed about the child's medical history, nutritional history and symptoms. A detailed physical examination was conducted by one of the study doctors. Weight was taken using a standardized uniscale 01-410-15 to the nearest $0.1 \mathrm{~kg}$ and height was taken using the Shorr portable infant/child length/height (Shorr productions, Olney, Maryland, USA) measuring board to the nearest 0.1 centimetre. HIV/AIDS clinical disease staging was determined using 
the World Health Organisation (WHO) classification for paediatric HIV/AIDS [10].

\section{Laboratory procedures}

Three to 5 millilitres $(\mathrm{ml})$ of blood was collected in a 5 $\mathrm{ml}$ trace element free vacutainer tube (Becton Dickinson, Franklin Lakes, N.J) by venepuncture from the cubital fossa or dorsum of the hand irrespective of when the last meal was eaten. The sample was centrifuged at $2000 \mathrm{~g}$ within one hour of collection. Serum was transferred into trace element-free cryo-tubes, and transported within 3 hours to a minus $20^{\circ} \mathrm{C}$ refrigerator until shipment. Zinc was analysed using Inductively Coupled Atomic Emission Spectrophotometry (ICPAES) [11] at the Clinical Chemistry Laboratory, Haukeland University Hospital, Bergen, Norway. The samples were digested using a microwave oven, nitric acid and concentrated hydrogen peroxide, as described by Rahil-Khazen et al [12]. The analytical coefficient of variation was about $3 \%$. An additional $2 \mathrm{ml}$ sample was collected in an EDTA containing vacutainer tube and analysed for haemoglobin, white cell count and CD4+ T cell count within 12 hours of collection. A complete blood count was performed using the Act 5Diff instrument (Beckman Coulter) and CD4 count was done using a FACScan instrument and MultiSET software (Beckman Dickinson). Qualitative C-reactive protein (CRP) was measured using the latex immunoassay on one drop of serum (Human Gesellschaft fur Biochemica und Diagnostica mbH, Germany). Distinct agglutination indicated a C-reactive protein (CRP) content $\geq 6 \mathrm{mg} / \mathrm{L}$. This rapid procedure was used in order to feedback the result to the attending paediatrician/doctor.

Low zinc was defined as a serum concentration below $10.0 \mu \mathrm{mol} / \mathrm{L}$ and an elevated CRP was defined as $\geq 6 \mathrm{mg} / \mathrm{L}$. We used the WHO definition for anaemia where by children aged 6 months to 5 years are considered to be anaemic if their haemoglobin levels are below $11 \mathrm{~g} / \mathrm{dl}$ [13]. We did not adjust the haemoglobin levels for ethnicity or altitude.

\section{Statistical issues}

Data were analysed using SPSS version 15. Categorical characteristics were summarised into proportions while continuous variables were analysed using means and standard deviations. Demographic, anthropometry and clinical characteristics were compared among zinc deficient (zinc less than $10.0 \mu \mathrm{mol} / \mathrm{L}$ ) and non deficient children using Fisher's exact test and odds ratios. All factors with a p-value of less than 0.20 by bivariate analysis were retained in the multiple logistic regression model to determine factors independently associated with low zinc. Weight for height (WHZ), height for age (HAZ) and weight for age (WAZ), z-scores were calculated using the WHO Anthro software and reference population [14] to assess anthropometric status.

\section{Results}

Of the 247 children analysed for serum zinc, 134 (54.3\%) had low zinc $<10 \mu \mathrm{mol} / \mathrm{L}$. Their mean (SD) age was 33.4 (13.8) with a range of 12.0 to 65.5 months. The male to female ratio was approximately $1: 1$.

\section{Clinical and haematological findings}

Generally the children were unhealthy. More than half $(141 / 247,57.1 \%)$ had cough, which was the commonest symptom, followed by skin rash in about half $(121 / 247$, $49.0 \%)$ and fever in a fifth $(94 / 247,17.8 \%)$ of the children. More than half of the children $(108 / 247,53.0 \%)$ were stunted, almost a quarter were underweight $(53 / 247$, $21.5 \%)$ and a tenth was wasted. Twenty five percent (62/ 247) had advanced HIV disease with WHO stage 3 or 4. Absolute CD4+ T cell count ranged from 46 - 3769 with a mean (SD) of 1129(615). One third of the children (85/ 247) were severely immune-compromised with CD4+ T cell counts of less than $20 \%$. Qualitative C-reactive protein was elevated in 100 out of $247(40.5 \%)$ children. The mean haemoglobin (SD) was $9.9(1.6) \mathrm{g} / \mathrm{dl}$ with a range of 4.6 $13.7 \mathrm{~g} / \mathrm{dl}$. Two thirds of the children (170/247, 68.8\%) were anaemic with haemoglobin of less than $11 \mathrm{~g} / \mathrm{dl}$.

There were no differences in sex, age, anthropometry, morbidity and CD4+ T cell count among those tested for zinc versus those who were not tested.

\section{Characteristics of children on HAART}

The children receiving HAART were older with a mean (SD) age of 42.3 (10.7) compared to the non-HAART group with 31.4 (13.7) months. Other descriptive characteristics were similar in HAART treated and HAART naïve children as shown in table 1 .

The proportion of HAART children who were tested for zinc $(44 / 85,55.0 \%)$ was significantly higher $(\mathrm{p}=0.00)$ than the non-HAART $(203 / 847,32.5 \%)$ children analyzed for zinc. The mean serum zinc among children on HAART was 12.2 (SD 4.1) compared to 9.6 (SD 2.5) among those not receiving HAART, a statistically significant difference (OR 2.6; 95\%CI 1.6 - 3.5). The mean duration of HAART was 10.2 months for the 13 zinc deficient and 9.5 months in children who were not zinc deficient, with a range of one to 21 months. Of the 44 children, 33 (75\%) had received ART for 12 or more months.

\section{Serum zinc and factors associated with low zinc concentrations}

The mean (SD) serum zinc concentration was 10.0 (2.9) $\mu \mathrm{mol} / \mathrm{L}$ with a range of $5.6-29.5 \mu \mathrm{mol} / \mathrm{L}$. There was no linear relationship between age, WHZ and haemoglobin versus zinc status as shown in Figure 2, 3 and 4. In 
Table 1 Characteristics of HIV infected children aged 1-5 years by HAART status at paediatric HIV clinics in Uganda

\begin{tabular}{lrrr}
\hline Variable (mean, SD) & HAART $(\mathbf{n}=\mathbf{4 4 )}$ & No HAART $(\mathbf{n}=\mathbf{2 0 3})$ & Mean difference (95\% Cl) \\
\hline Age in months & $42.3(10.7)$ & $31.4(13.7)$ & $10.9(6.6-15.2)$ \\
Weight for height z score & $0.7(1.4)$ & $-0.2(1.4)$ & $0.9(0.4-1.4)$ \\
Weight for age z score & $-0.7(1.1)$ & $-1.3(1.3)$ & $0.6(0.2-1.0)$ \\
Height for age z score & $-2.1(1.4)$ & $-2.1(1.6)$ & $0.0(-0.5-0.5)$ \\
Haemoglobin $(\mathrm{g} / \mathrm{dl})$ & $10.9(1.2)$ & $9.8(1.6)$ & $1.1(0.6-1.6)$ \\
Absolute CD4+ cell count $(\mathrm{cell} / \mathrm{s} / \mu \mathrm{L}$ & $1132(664)$ & $1128(607)$ & $6(-198-206)$ \\
Serum zinc $(\mu \mathrm{mol} / \mathrm{L})$ & $12.2(4.1)$ & $9.6(2.5)$ & $2.6(1.6-3.5)$ \\
\hline
\end{tabular}

addition there was no significant difference in mean age, anthropometry, haemoglobin and CD4+ cell count among children with low serum zinc $(<10 \mu \mathrm{mol} / \mathrm{L}) \mathrm{com}-$ pared to those with normal zinc levels (table 2).

Factors associated with low serum zinc concentrations at bivariate analysis were: being HAART naïve, reported fever, underweight, WHO stage 3 or 4 disease and elevated CRP (table 3 ). The mean (SD) serum zinc among CRP negative children was 10.2 (2.5) compared to 9.8 (3.6) in CRP positive children. This difference was not statistically significant.

In the multivariate model the only significant independent predictors of low zinc were: being HAART naïve and reported fever. Of the 44 children on HAART, 13 (29.5\%) had low serum zinc compared to 121 of 203 (59.6\%) in the non-HAART group. This difference was statistically significant [Adjusted OR 3.7 (95\% CI 1.87.7)]. When fever was excluded from the model elevated CRP was a significant predictor of low zinc, illustrating that fever and CRP are closely related.

\section{Discussion}

The prevalence of zinc deficiency in this group of HIV infected children aged 1-5 years attending paediatric

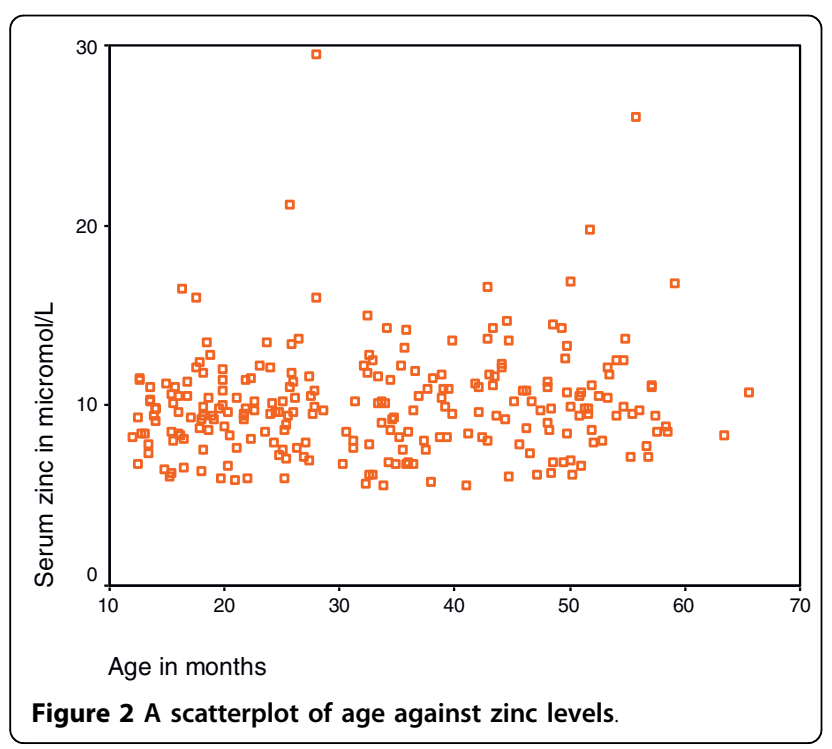

HIV clinics in Uganda was high (54.3\%). This was higher than what was reported in a previous study of children aged 6-36 months with persistent diarrhoea but of undetermined HIV status at Mulago hospital, Uganda [15]. While we used a cut off of $10 \mu \mathrm{mol} / \mathrm{L}$ to indicate zinc deficiency, the previous study had used $4.73 \mu \mathrm{mol} / \mathrm{L}$ assuming a normal serum zinc level of 8.99 (SD 2.13) $\mu \mathrm{mol} / \mathrm{L}$ measured from a control group of healthy children. What was regarded as normal is below the mean (SD) serum zinc of 10.0 (2.9) reported in our study. An earlier community study in Kampala had found a serum zinc range of $8.4-20.9 \mu \mathrm{mol} / \mathrm{L}$ [mean(SD) 10.1(3.2)] among children aged 4-14 years [16]. Based on these two previous studies, it is possible that the zinc status in our study is similar to zinc levels in the general population of children in a similar age group in Uganda. The prevalence was twice as high in children who had not yet started HAART compared to those receiving HAART. This was not influenced by the duration on HAART. This implies that HAART may protect against zinc deficiency but will not completely eliminate it.

Compared to other studies of HIV infected children in Africa, the prevalence of zinc deficiency was higher than

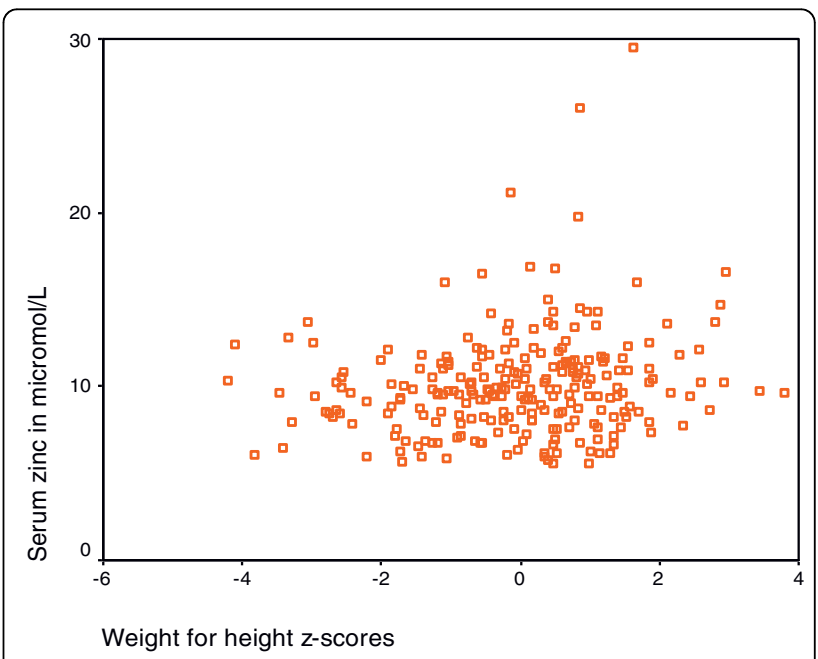

Figure 3 A scatterplot of weight for height z-scores versus zinc levels. 


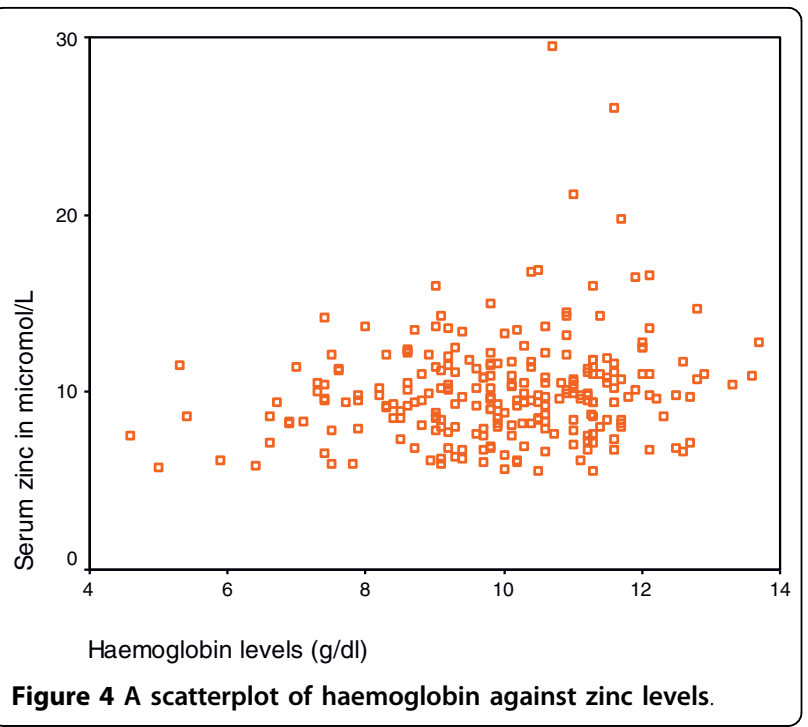

what was reported in South Africa and Rwanda [17,18]. Our study had a larger sample size and older children compared to the two studies which enrolled children from 2 months of age.

We did not find any association between age and zinc status in our study. All the children enrolled in this study were above one year of age, very few of whom were still breastfeeding. Other studies have shown that micronutrient deficiencies are less likely to occur below 24 months of age [17] and that breastfeeding is protective [19] against low serum zinc. Further more, there was no significant difference in mean zinc concentrations between girls and boys. Similar findings were reported from children whose HIV status was not known in low-income families in California [20].

Surprisingly, there was no significant association between zinc status and diarrhoea in the current study, possibly because there were very few children with diarrhoea. Studies in other developing countries have shown an association between low zinc and diarrhoea [21]. As expected, the presence of fever was significantly associated with low zinc levels. Fever is an indicator of infection and this may be associated with increased acute phase proteins and consequently reduced serum zinc [22]. Other common illnesses such as cough and skin rash were not associated with low zinc either.

There was a weak association between underweight and zinc status although a previous Uganda study of children with persistent diarrhoea [15] and a South Africa study of HIV infected children [17] did not find any association between zinc and nutritional status. Some authors have shown that severely malnourished children have a higher anti-oxidant activity and this is associated with low serum zinc [19]. Although anaemic children were more likely to have low zinc, the association was not significant. Other studies in zinc deficient low-income countries such as India and Cambodia have reported a close association between zinc deficiency and anaemia $[19,23]$. The lack of association in our study could not be explained.

Advanced HIV disease (WHO stage 3 and 4) was associated with low serum zinc but probably confounded by other factors. Advanced HIV disease is more likely to be associated with recurrent acute infections and an elevated acute phase response interpreted as low zinc. Our findings are similar to a South African study where the prevalence of zinc deficiency increased with HIV disease staging [6]. CD4+ T cell count had no association with zinc status in the current study. This finding is similar to what was reported in studies of HIV infected adults at Tufts university and Medical Centre in the nutrition for health living cohort [24] and in South Africa [6].

Children who were on HAART were less likely to be zinc deficient. This is further supported by a study in adults that showed that patients receiving HAART have better micronutrient indices including zinc than those not yet on HAART [25]. However, two other studies indicated that zinc deficiency remains highly prevalent in HIV infected adults on HAART [7,24].

We acknowledge that infant, child feeding practices and maternal HIV status influence the diet and mode of feeding [26], and may subsequently affect zinc intake. Adult studies have shown that the time of blood

Table 2 Characteristics of HIV infected children aged 1-5 years by zinc status at paediatric HIV clinics in Uganda

\begin{tabular}{|c|c|c|c|c|}
\hline Variable (mean, SD) & Serum zinc $<10 \mu \mathrm{mol} / \mathrm{L}$ & $95 \% \mathrm{Cl}$ & Serum zinc $=10 \mu \mathrm{mol} / \mathrm{L}$ & $95 \% \mathrm{Cl}$ \\
\hline Age in months & $32.2(14.0)$ & 29.8 to 34.6 & 34.7 (13.6) & 32.2 to 37.2 \\
\hline $\begin{array}{l}\text { Weight for height } \\
\text { z score }\end{array}$ & $-0.2(1.4)$ & -0.5 to 0.0 & $0.1(1.5)$ & -0.2 to 0.4 \\
\hline Weight for age $z$ score & $-1.4(1.3)$ & -1.6 to -1.2 & $-1.0(-1.3)$ & -1.2 to -0.7 \\
\hline Height for age z score & $-2.3(1.4)$ & -2.5 to -2.0 & $-1.9(1.8)$ & -2.3 to -1.6 \\
\hline Haemoglobin (g/dl) & $9.7(1.7)$ & 9.5 to 10.0 & $10.2(1.5)$ & 9.7 to 10.5$)$ \\
\hline Absolute CD4+ cell count (cells/ $\mu$ L) & $1056(613)$ & 950 to 1162 & $1214(610)$ & 1099 to 1330 \\
\hline${ }^{*}$ On HAART $(n, \%)$ & $13(29.5)$ & & $31(70.5)$ & \\
\hline
\end{tabular}

${ }^{*}$ Children on HAART are expressed as a percentage (\%). 
Table 3 Factors associated with low zinc in 247 HIV infected Ugandan children aged 1-5 years

\begin{tabular}{|c|c|c|c|c|c|}
\hline Variable & No. of children & $\begin{array}{r}\text { Low zinc }<10 \mu \mathrm{mol} / \mathrm{L} \\
(\mathrm{n} ; \%)\end{array}$ & Unadjusted OR $(95 \% \mathrm{Cl})$ & $p$-value & Adjusted OR $(95 \% \mathrm{Cl})$ \\
\hline $\begin{array}{l}\text { Age }<36 \text { months } \\
\text { Age } \geq 36 \text { months }\end{array}$ & $\begin{array}{l}146 \\
101\end{array}$ & $\begin{array}{l}86(58.2) \\
49(48.5)\end{array}$ & $1.5(0.9-2.5)$ & 0.153 & $1.0(0.6-1.8)$ \\
\hline $\begin{array}{l}\text { Male } \\
\text { Female }\end{array}$ & $\begin{array}{l}128 \\
119\end{array}$ & $\begin{array}{l}75(58.6) \\
59(49.6)\end{array}$ & $1.4(0.9-2.4)$ & 0.162 & $0.7(0.4-1.1)$ \\
\hline $\begin{array}{l}\text { On HAART } \\
\text { No HAART }\end{array}$ & $\begin{array}{r}44 \\
203\end{array}$ & $\begin{array}{l}13(29.5) \\
121(59.6)\end{array}$ & $3.5(1.7-7.1)$ & 0.000 & $3.7(1.8-7.7)$ \\
\hline $\begin{array}{l}\text { Reported fever } \\
\text { No fever }\end{array}$ & $\begin{array}{r}44 \\
203\end{array}$ & $\begin{array}{r}30(68.2) \\
104(51.2)\end{array}$ & $2.0(1.0-4.1)$ & 0.046 & $2.2(1.1-4.6)$ \\
\hline $\begin{array}{l}\text { Current diarrhoea } \\
\text { No Diarrhoea }\end{array}$ & $\begin{array}{r}20 \\
227\end{array}$ & $\begin{array}{r}15(75.0) \\
119(52.4)\end{array}$ & $2.7(1.0-7.7)$ & 0.062 & $2.2(0.8-6.7)$ \\
\hline $\begin{array}{l}\text { Cough present } \\
\text { No cough }\end{array}$ & $\begin{array}{l}141 \\
106\end{array}$ & $\begin{array}{l}81(57.4) \\
53(50.0)\end{array}$ & $1.4(0.8-2.2)$ & 0.249 & \\
\hline $\begin{array}{l}\text { WHO stage } 3 \text { or } 4 \\
\text { WHO stage } 1 \text { or } 2\end{array}$ & $\begin{array}{r}62 \\
185\end{array}$ & $\begin{array}{l}42(67.7) \\
92(49.7)\end{array}$ & $2.1(1.2-3.9)$ & 0.018 & $1.5(0.8-2.9)$ \\
\hline $\begin{array}{l}\text { WHZ score }<-2 \\
\text { WHZ score } \geq-2\end{array}$ & $\begin{array}{r}24 \\
223\end{array}$ & $\begin{array}{r}15(62.5) \\
119(53.4)\end{array}$ & $1.5(0.6-3.5)$ & 0.519 & \\
\hline $\begin{array}{l}\text { WAZ score }<-2 \\
\text { WAZ score } \geq-2\end{array}$ & $\begin{array}{r}56 \\
191\end{array}$ & $\begin{array}{l}38(67.9) \\
96(50.3)\end{array}$ & $2.1(1.1-3.9)$ & 0.022 & $1.2(0.6-2.6)$ \\
\hline $\begin{array}{l}\text { HAZ score }<-2 \\
\text { HAZ score } \geq-2\end{array}$ & $\begin{array}{l}136 \\
111\end{array}$ & $\begin{array}{l}80(58.8) \\
54(48.6)\end{array}$ & $1.5(0.9-2.5)$ & 0.124 & $1.3(0.8-2.3)$ \\
\hline $\begin{array}{l}C R P<6 \mathrm{mg} / \mathrm{L} \\
C R P \geq 6 \mathrm{mg} / \mathrm{L}\end{array}$ & $\begin{array}{l}147 \\
100\end{array}$ & $\begin{array}{l}72(49.0) \\
62(62.0)\end{array}$ & $1.7(1.0-2.9)$ & 0.051 & $1.6(0.9-2.7)$ \\
\hline $\begin{array}{l}\mathrm{Hb}<11 \mathrm{~g} / \mathrm{dl} \\
\mathrm{Hb} \geq 11 \mathrm{~g} / \mathrm{dl}\end{array}$ & $\begin{array}{r}170 \\
77\end{array}$ & $\begin{array}{l}98(57.6) \\
36(46.8)\end{array}$ & $1.6(0.9-2.7)$ & 0.130 & $1.1(0.6-2.0)$ \\
\hline $\begin{array}{l}\text { CD4 }<20 \% \\
C D 4 \geq 20 \%\end{array}$ & $\begin{array}{r}85 \\
162\end{array}$ & $\begin{array}{l}52(61.2) \\
82(50.6)\end{array}$ & $1.5(0.9-2.5)$ & 0.139 & $1.1(0.6-1.9)$ \\
\hline
\end{tabular}

collection and feeding influence zinc levels [27], factors not controlled for in this study. The exclusions though numerous, were not systematic and therefore less likely to influence the results of our study. Low zinc levels were associated with fever or CRP implying that infection and acute phase proteins may have influenced the zinc status of the study children. Other researchers have previously confirmed that serum zinc is affected by the serum protein level and any acute-phase reactions [28]. Although the concentration of serum zinc gives limited information on the total zinc content in the body, there is no better way of determining zinc status that has been established [29]. The generalisability of this study is limited to the HIV infected children since we did not have a control group of HIV un-infected children.

Coupled with the already existing poor nutritional and immunological status, low zinc status in Ugandan HIV infected children is likely to remain a significant contributor to increased morbidity especially among those not yet receiving HAART.

\section{Conclusion}

While almost two thirds of untreated HIV infected children were zinc deficient, zinc deficiency occurred in only a third of those on HAART. Increased access to HAART among HIV infected children living in Uganda might reduce the prevalence of zinc deficiency in this population.

\section{Acknowledgements}

We thank the children, their parents/caretakers, the paediatricians in the study sites, research assistants and the laboratory personnel, who participated in the study. The study was part of a collaboration between the Department of Paediatrics and Child Health, Makerere University and Centre for International Health, University of Bergen under the project "Essential Nutrition and Child Health in Uganda", funded by the Norwegian Government Fund for Higher Education (NUFU). The funders had no role in the conceptualisation, design and implementation of the study.

\section{Author details}

'Department of Paediatrics and Child Health, School of Medicine, College of Health Sciences, Makerere University, Kampala, Uganda. ${ }^{2}$ Centre for International Health, University of Bergen, Norway. ${ }^{3}$ Institute of Medicine, University of Bergen, and Laboratory of Clinical Biochemistry, Haukeland University Hospital, Bergen, Norway.

\section{Authors' contributions}

GN, TT and JKT participated in the conception, design and implementation of the study, statistical analysis, interpretation and drafting of the manuscript. CMN participated in study design and drafting of the manuscript. BJB analysed the serum samples for zinc and participated in drafting the manuscript. All authors read and approved the final manuscript.

\section{Competing interests}

The authors declare that they have no competing interest.

Received: 18 March 2010 Accepted: 21 September 2010 Published: 21 September 2010 
References

1. Fischer Walker CL, Ezzati M, Black RE: Global and regional child mortality and burden of disease attributable to zinc deficiency. Eur J Clin Nutr 2009, 63(5):591-597.

2. Brown KH, Rivera JA, Bhutta Z, Gibson RS, King JC, Lonnerdal B, Ruel MT, Sandtrom B, Wasantwisut E, Hotz C: International Zinc Nutrition Consultative Group (IZiNCG) technical document \#1. Assessment of the risk of zinc deficiency in populations and options for its control. Food Nutr Bull 2004, 25(1 Suppl 2):S99-203.

3. Bhaskaram P: Micronutrient malnutrition, infection, and immunity: an overview. Nutr Rev 2002, 60(5 Pt 2):S40-45.

4. O'Dell BL: Role of zinc in plasma membrane function. J Nutr 2000, 130(5S Suppl):1432S-1436S.

5. Baum M, Campa A, Lai S, Lai H, Page J: Zinc status in human immunodeficiency virus type 1 infection and illicit drug use. Clin Infect Dis 2003, 37(Suppl 2):S117-123.

6. Visser ME, Maartens G, Kossew G, Hussey GD: Plasma vitamin A and zinc levels in HIV-infected adults in Cape Town, South Africa. Br J Nutr 2003, 89(4):475-482

7. Wellinghausen $N$, Kern $W$, Jochle $W$, Kern P: Zinc serum level in human immunodeficiency virus-infected patients in relation to immunological status. Biol Trace Elem Res 2000, 73(2):139-149.

8. Henderson RA, Talusan K, Hutton N, Yolken RH, Caballero B: Serum and plasma markers of nutritional status in children infected with the human immunodeficiency virus. J Am Diet Assoc 1997, 97(12):1377-1381.

9. WHO: Antiretroviral Therapy for HIV Infection in Infants and Children in Resource-Limited Settings: Towards Universal Access. Geneva, Switzerland 2006.

10. WHO: Case definitions of HIV for surveillance and revised clinical staging and immunological classification of HIV-related disease in adults and children. Geneva, Switzerland 2006

11. Bolann B, Rahil-Khazen R, Henriksen H, Isrenn R, Ulvik R: Evaluation of methods for trace-element determination with emphasis on their usability in the clinical routine laboratory. Scand J Clin Lab Invest 2007, 67(4):353-366

12. Rahil-Khazen $\mathrm{R}$, Henriksen $\mathrm{H}$, Bolann BJ, Ulvik RJ: Validation of inductively coupled plasma atomic emission spectrometry technique (ICP-AES) for multi-element analysis of trace elements in human serum. Scand J Clin Lab Invest 2000, 60(8):677-686.

13. WHO: Worldwide prevalence of anaemia 1993-2005. Geneva, Switzerland 2008.

14. WHO: WHO Anthro 2005. Geneva, Switzerland 2005

15. Bitarakwate $E$, Mworozi E, Kekitiinwa A: Serum zinc status of children with persistent diarrhoea admitted to the diarrhoea management unit of Mulago Hospital, Uganda. Afr Health Sci 2003, 3(2):54-60.

16. Bimenya GS, Lutalo-Bosa AJ, Nzaro E: Serum zinc levels in normal children $(\mathrm{HbAA})$ and sickle cell children (HbSS) in and around Kampala. East Afr Med J 1980, 57(12):825-827.

17. Eley BS, Sive AA, Abelse L, Kossew G, Cooper M, Hussey GD: Growth and micronutrient disturbances in stable, HIV-infected children in Cape Town. Ann Trop Paediatr 2002, 22(1):19-23.

18. Ndagije F, Baribwira C, Coulter JB: Micronutrients and T-cell subsets: comparison between HIV-infected and uninfected, severely malnourished Rwandan children. Ann Trop Paediatr 2007, 27(4):269-275.

19. Thakur S, Gupta N, Kakkar P: Serum copper and zinc concentrations and their relation to superoxide dismutase in severe malnutrition. Eur $J$ Pediatr 2004, 163(12):742-744

20. Schneider JM, Fujii ML, Lamp CL, Lonnerdal B, Zidenberg-Cherr S: The prevalence of low serum zinc and copper levels and dietary habits associated with serum zinc and copper in 12- to 36-month-old children from low-income families at risk for iron deficiency. J Am Diet Assoc 2007, 107(11):1924-1929.

21. Bhandari N, Bahl R, Hambidge KM, Bhan MK: Increased diarrhoeal and respiratory morbidity in association with zinc deficiency-a preliminary report. Acta Paediatr 1996, 85(2):148-150.

22. Duggan C, MacLeod WB, Krebs NF, Westcott JL, Fawzi WW, Premji ZG, Mwanakasale V, Simon JL, Yeboah-Antwi K, Hamer DH: Plasma zinc concentrations are depressed during the acute phase response in children with falciparum malaria. J Nutr 2005, 135(4):802-807.
23. Anderson V, Jack S, Monchy D, Hem N, Hok P, Bailey K, Gibson R: Coexisting micronutrient deficiencies among stunted Cambodian infants and toddlers. Asia PaC J Clin Nutr 2008, 17(1):72-79.

24. Jones CY, Tang AM, Forrester JE, Huang J, Hendricks KM, Knox TA, Spiegelman D, Semba RD, Woods MN: Micronutrient levels and HIV disease status in HIV-infected patients on highly active antiretroviral therapy in the Nutrition for Healthy Living cohort. J Acquir Immune Defic Syndr 2006, 43(4):475-482.

25. Rousseau MC, Molines C, Moreau J, Delmont J: Influence of highly active antiretroviral therapy on micronutrient profiles in HIV-infected patients. Ann Nutr Metab 2000, 44(5-6):212-216.

26. Fadnes $L T$, Engebretsen IM, Wamani $H$, Semiyaga NB, Tylleskar $T$, Tumwine JK: Infant feeding among HIV-positive mothers and the general population mothers: comparison of two cross-sectional surveys in Eastern Uganda. BMC Public Health 2009, 9:124.

27. Hambidge KM, Goodall MJ, Stall C, Pritts J: Post-prandial and daily changes in plasma zinc. J Trace Elem Electrolytes Health Dis 1989, 3(1):55-57.

28. Wieringa FT, Dijkhuizen MA, West CE, Northrop-Clewes CA, Muhilal : Estimation of the effect of the acute phase response on indicators of micronutrient status in Indonesian infants. J Nutr 2002, 132(10):3061-3066.

29. Thompson RP: Assessment of zinc status. Proc Nutr Soc 1991, 50(1):19-28.

\section{Pre-publication history}

The pre-publication history for this paper can be accessed here: http://www.biomedcentral.com/1471-2431/10/68/prepub

doi:10.1186/1471-2431-10-68

Cite this article as: Ndeezi et al:: Zinc status in HIV infected Ugandan children aged 1-5 years: a cross sectional baseline survey. BMC Pediatrics 2010 10:68.

\section{Submit your next manuscript to BioMed Central and take full advantage of:}

- Convenient online submission

- Thorough peer review

- No space constraints or color figure charges

- Immediate publication on acceptance

- Inclusion in PubMed, CAS, Scopus and Google Scholar

- Research which is freely available for redistribution

Submit your manuscript a www.biomedcentral.com/submit
Biomed Central 